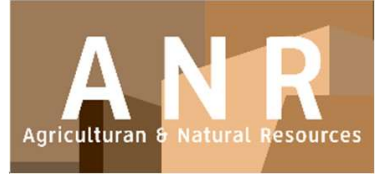

PAPER - OPEN ACCESS

Logam Berat Tembaga $(\mathrm{Cu})$ Dan Timbal $(\mathrm{Pb})$ Pada Mangrove Avicenia marina Dan Pengaruhnya Terhadap Kualitas Air Laut Di Kawasan Pesisir Belawan Sumatera Utara

\author{
Author : Yunasfi dkk., \\ DOI $\quad: 10.32734 /$ anr.v3i1.843 \\ Electronic ISSN $\quad: 2654-7023$ \\ Print ISSN : :2654-7015
}

Volume 3 Issue 1-2020 TALENTA Conference Series: Agriculturan \& Natural Resource (ANR)

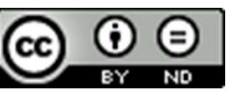

This work is licensed under a Creative Commons Attribution-NoDerivatives 4.0 International License.

Published under licence by TALENTA Publisher, Universitas Sumatera Utara

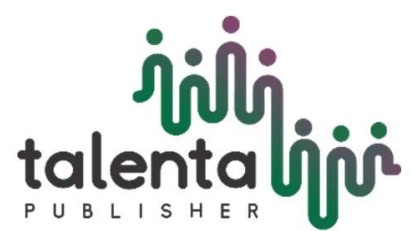




\section{Logam Berat Tembaga (Cu) Dan Timbal (Pb) Pada Mangrove Avicenia marina Dan Pengaruhnya Terhadap Kualitas Air Laut Di Kawasan Pesisir Belawan Sumatera Utara}

\author{
Yunasfia $^{\mathrm{a}}$, Dian Sartika Tampubolon ${ }^{\mathrm{a}}$, Budi Utomo ${ }^{\mathrm{a}}$ \\ ${ }^{a}$ Program Studi Kehutanan, Fakultas Kehutanan, Universitas Sumatera Utara Jl. Tridarma Ujung No. 1 Kampus USU Medan 20155, Indonesia \\ yunasfijamhar@yahoo.co.id
}

\begin{abstract}
Abstrak
Kajian ini dilakukan pada lokasi Desa Nelayan di Belawan. Tujuan dari penelitian ini ialah untuk menganalisis kandungan logam berat $\mathrm{Cu}$ dan $\mathrm{Pb}$ pada bagian tubuh tumbuhan A.marina yaitu bagian akar kawat, akar pasak, kulit batang, daun dan sedimen, sehingga dapat dijadikan akumulator pencemaran logam berat dikawasan hutan mangrove. Analisis logam $\mathrm{Cu}$ dan $\mathrm{Pb}$ lakukan di Laboratorium Penelitian Fakultas Farmasi, Universitas Sumatera Utara dengan menggunakan metode Atomic Absorption Spectrophotometric (AAS). Dari hasil penelitian menunjukkan bahwa kandungan logam berat $\mathrm{Cu}$ mempunyai nilai rata-rata yang lebih besar dibandingkan kadungan logam berat $\mathrm{Pb}$ pada $A$. marina. Kemampuan A. marina dalam mengakumulasi logam berat $\mathrm{Cu}$ dan $\mathrm{Pb}$ dapat dikategorikan rendah dengan nilai logam berat $\mathrm{Cu} 6,17755$ sedangan logam berat $\mathrm{Pb} 5,4484$ yang artinya $\mathrm{BCF}$ pada akumulasi logam berat $\mathrm{Cu}$ dan $\mathrm{Pb}<200$ dan di kategorikan rendah.
\end{abstract}

Kata kunci: Avicennia marina; $\mathrm{Cu}$ and $\mathrm{P}$; Mangrove

\section{Pendahuluan}

Hutan mangrove merupakan formasi dari tumbuhan yang spesifik, dan umumnya dijumpai tumbuh dan berkembang pada kawasan pesisir yang terlindung di daerah tropika dan subtropika. Kata mangrove sendiri berasal dari perpaduan antara bahasa Portugis yaitu mangue, dan bahasa Inggris yaitu grove Dalam bahasa Portugis, kata mangrove dipergunakan untuk individu jenis tumbuhan, dan kata mangal digunakan untuk komunitas hutan yang terdiri atas individu-individu jenis mangrove. Sedangkan dalam bahasa Inggris, kata mangrove digunakan baik untuk komunitas pohon-pohonan atau rumput yang tumbuh di kawasan pesisir maupun untuk individu jenis tumbuhan lainnya yang tumbuh yang berasosiasi dengan mangrove tersebut. Namun, [1] menyebutkan bahwa kata mangrove adalah berasal dari bahasa Melayu-kuno, yaitu mangi-mangi yang digunakan untuk menerangkan marga Avicennia, dan sampai saat ini istilah tersebut masih digunakan untuk kawasan Maluku. Berkaitan dengan hal tersebut, berbagai macam istilah yang digunakan untuk memberikan sebutan pada hutan mangrove, antara lain adalah coastal woodland, mangal dan tidal forest [2].

Vegetasi mangrove hanya tumbuh pada pantai yang terlindung dari gerakan gelombang, bila keadaan pantai sebaliknya, benih tidak mampu tumbuh dengan sempurna. Ekosistem mangrove berada di wilayah pesisir yang merupakan daerah pertemuan antara ekosistem darat dan laut. Lingkup ekosistem ini dibagi menjadi dua, yaitu:

1. Ke arah darat meliputi bagian tanah baik yang kering maupun yang terendam air laut, dan masih dipengaruhi oleh sifat-sifat fisik laut seperti pasang surut, ombak dan gelombang serta perembesan air laut. 
2. Ke arah laut mencakup bagian perairan laut dan dipengaruhi oleh proses alami yang terjadi di darat seperti sedimentasi serta aliran air tawar dari sungai termasuk yang disebabkan oleh kegiatan manusia di darat seperti penggundulan hutan, pembuangan limbah, perluasan permukiman serta intensifikasi pertanian.

Walau demikian, hutan mangrove merupakan ekosistem yang dinamis dan memiliki kemampuan pulih dengan cepat jika kondisi geomorfologi dan hidrologi serta komposisi habitat tidak diubah oleh penggunaannya [3].

Tumbuhan mangrove mempunyai kecenderungan untuk mengakumulasikan logam-logam berat yang terdapat dalam ekosistem tempat tumbuhan hidup. Kemampuan akumulasi logam berat tersebut berbeda untuk setiap spesies tanaman yang berbeda serta mempunyai kapasitas akumulasi yang berbeda pula. Meskipun faktor akumulasi diferensial (persamaan matematika untuk fungsi satu variabel atau lebih) antara spesies-spesies relatif tetap. distribusi unsur-unsur hara dan garam-garam mineral tidak sama di setiap bagian tumbuhan. Tumbuhan mangrove mengakumulasi logam berat paling tinggi terdapat di bagian akar. Namun demikian faktor lain seperti rnobilitas dan kelarutan logarn juga berpengaruh terhadap akumulasi logarn berat dalam turnbuhan. Berdasarkan rnobilitas dan kelarutannya. Kemampuan tumbuhan untuk mengakumulasikan logam berat sesuai dengan urutan sebagai berikut: $\mathrm{Mn}>\mathrm{Cr}>\mathrm{Cu}>\mathrm{Cd}>\mathrm{Pb}$. Berdasarkan urutan tersebut kemampuan tumbuhan untuk mengakumulasi Mn lebih besar dari $\mathrm{Cr}$, kemampuan mengakumulasi $\mathrm{Cr}$ lebih besar dari $\mathrm{Cu}$ dan seterusnya. Selain kemampuan untuk mengakumulasi logam berat berbeda untuk setiap spesies, konsentrasi logam berat antar organ tumbuhan seperti akar, cabang, daun juga berbeda dalam satu spesies. Perbedaan konsentrasi logam berat pada organ tumbuhan tertentu berkaitan dengan proses fisiologis tumbuhan tersebut [4].

\subsection{Tujuan Penelitian}

Untuk mengetahui kemampuan Avicenia marina dalam mengakumulasikan logam berat $(\mathrm{Cu})$ dan $(\mathrm{Pb})$ yang terdapat pada akar kawat, akar pasak, kulit batang dan daun di hutan mangrove yang berada di Desa Nelayan Belawan Sumatera Utara.

\subsection{Manfaat Penelitian}

Dapat memberikan informasi mengenai akumulasi logam berat $\mathrm{Cu}$ dan $\mathrm{Pb}$ secara kuantitatif pada bagaian akar kawat, akar pasak, daun dan kulit batang pohon A. marina yang berada di Desa Nelayan Belawan Sumatera Utara.

Dapat memberikan informasi bagi masyarakat agar menanami mangrove jenis A. marina karena dapat dijadikan sebagai pengumpul (akumulator) logam berat sehingga peranan ekologis dari spesies ini dapat mempertahankan kualitas air.

\section{Metode Penelitian}

\subsection{Lokasi Penelitian}

Penelitian ini dilaksanakan pada satu lokasi pengamatan di kawasan pesisir Belawan di Hutan Mangrove Desa Nelayan. Tempat ini merupakan tempat yang telah tercemar karena terletak disekitaran tempat penampungan ataupun tempat pembuangan limbah industri di sekitar lokasi tersebut. Analisa logam berat dilakukan di Laboratorium Penelitian Fakultas Farmasi, Universitas Sumatera Utara. Penelitian ini dilaksanakan bulan November sampai bulan Januari 2019.

Desa Nelayan ini berada di kecamatan Medan Labuhan, dengan luas daerah 520 ha. Batas-batas wilayah pada desa ini adalah sebagai berikut:

1. Sebelah utara berbatasan dengan Sei Deli atau Kelurahan Belawan Bahari

2. Sebelah selatan berbatasan dengan Sei Mati

3. Sebelah barat berbatasan dengan Pekan Labuhan

4. Sebelah timur berbatasan dengan P. L Tiram / Sei Pegatalan 


\subsection{Alat dan Bahan}

Alat yang digunakan dalam penelitian ini adalah pisau, kamera digital, kompas, cangkul, botol yang kecil, thermometer, pita ukur, kertas lakmus , hand refractometer, mortal, dan pasile, timbangan analitik, tanur, krus porselin, gelas ukur, pemanas (hot plate), labu Erlenmeyer, kertas saring Whatman 42, Spektrofotomentri serapan atom, wadah sampel, labu takar, gelas Beaker, oven, corong, pipet tetes, spatula dan pipet volume.

Bahan yang digunakan dalam penelitian ini adalah Tally sheet yang digunakan untuk pengambilan sampel, alat tulis, rali rafia, larutan $\mathrm{HNO}^{3}$ pekat, aquades, larutan standart $\mathrm{Cu}$ maupun $\mathrm{Pb}$, Aluminium foil, plastik sampel, sampel A. marina yang merupakan bagian akar kawat, akar pasak dan daun A. marina yang merupakan daun tua dan daun muda, sampel sedimen yang ada dibawah tegakan pohon dan sampel air laut.

\subsection{Prosedur Kerja}

\subsubsection{Pengambilan Fungi}

Pengambilan sampel dilakukan dengan mengikuti jalur transek tegak lurus pantai secara acak. Bagian yang diambil adalah akar kawat, akar pasak, daun tua dan daun muda, kulit batang dari pohon A. marina bagian akar yang diambil adalah akar pasak dan akar napas yang ada didalam sedimen, untuk sampel kulit batang A. marina yang diambil adalah yang terkena pasang air laut. Dari jalur transek tersebut diambil 3 sampel pada tiap lokasi dengan jarak pengambilan sampel 50 meter. Pengambilan sampel air dilakukan pada waktu pagi pukul 08.00 WIB hingga Pukul 10.00 WIB, siang hari pada pukul 13.00 WIB sampai dengan 15.00 WIB, dan sore hari pukul 16.00 sampai 18.00 WIB. Pengambilan sedimen di kedalaman kurang lebih $30 \mathrm{~cm}$ serta dilakukan pengukuran parameter kualitas air seperti suhu udara, drajat keasaman, dan salinitas pada lokasi pengambilan sampel.

\subsubsection{Preparasi Sampel Akar Kawat, Akar Pasak, Daun, Kulit Batangdan Sedimen}

Sampel akar kawat, akar pasak, daun, kulit batang dan sedimen dihomogenkan dengan menggunakan sampel yang diambil dari tiga titik pengambilan pada setiap tempat. Untuk preparasi akar kawat, akar pasak, daun dan kulit batang dilakukan pemotongan kecil-kecil dan dihaluskan. Sampel sedimen dapat langsung dihaluskan. Setelah dikeringkan dalam oven dengan suhu $105^{\circ} \mathrm{C}$ sampai kadar air konstan. Kemudian semua sampel dihomogenkan dengan ditimbang $5 \mathrm{~g}$, kemudian dilakukan pengarangan dengan menggunakan pemanas (hot plate) sampai menjadi arang. Untuk mempercepat pengarangan maka diteteskan laurutan $\mathrm{HNO}^{3}$ secara sedikit demi sedikit berguna untuk menghindari kabut. Sampel yang berubah menjadi arang dimasukkan kedalam tanur dengan suhu $700{ }^{\circ} \mathrm{C}$ sampai menjadi abu. Setelah seesai pengabuan sampel dan sedimen dilarutkan dengan menambahkan air pada $10 \mathrm{ml}$ larutan $\mathrm{HNO}^{3}$ pekat.

Hasil pencampuran terus digerus didalam wadah krus porselin secara merata kemudian disatung kedalam labu ukur $25 \mathrm{ml}$ dengan menggunakan kertas saring. Krus porselin yang selesai digerus dapat dibilas menggunakan akuades sebanyak dua kali. Setelah dilakukan penyaringan tambahkan aquades hingga garis batas dilabu ukur 25 ml. Larutan yang diperoleh siap untuk dianalisis dengan menggunakan Atomic Absorption Spectrophotometry (AAS).

\subsubsection{Preparasi Sampel Air}

Sampel air laut disaring menggunakan kertas saring dan kemudian diukur sebanyak $100 \mathrm{ml}$. Setelah itu ditambahkan $10 \mathrm{ml}$ larutan HNO 3 pekat. Panaskan wadah Erlenmeyer diatas pemanas (hot plate) sampai volumenya berkurang menjadi $35 \mathrm{ml}$. Kemudian diendapkan, larutan yang diendapkan kemudian disaring fasa airnya dengan kertas saring. Larutan yang diperoleh siap untuk dianalisis dengan menggunakan alat Atomic Absorption Spectrophotometry (AAS).

\subsubsection{Pembuatan Larutan Standart $\mathrm{Cu}$ dan $\mathrm{Pb}$}

Larutan induk $\mathrm{Cu}$ maupun $\mathrm{Pb}$ yang memiliki konsentrasi 1000 ppm masing-masing dipipet banyak $10 \mathrm{ml}$, lalu dimasukkan kelabu ukur $100 \mathrm{ml}$. Kemudian ditambahkan aquades sampai batas tanda akhir. Larutan yang didapati mengandung 100 ppm. Dari larutan 100 ppm dipipet sebanyak $10 \mathrm{ml}$, lalu dimasukkan kedalam labu ukur $100 \mathrm{ml}$ dengan menambahkan aquades sampai garis batas akhir untuk mendapatkan larutan dengan konsentrasi 10 ppm. 
Didapati larutan standar dengan konsentrasi 0,2;0,4, 0,6, 0,8 dan 1 ppm, berturut-turut dipipet sebanyak 2 ml. 4 $\mathrm{ml}, 6 \mathrm{ml}, 8 \mathrm{ml}$ dan $10 \mathrm{ml}$ dari larutan $10 \mathrm{ppm}$ lalu masing-masing dimasukkan kedalam labu ukur $100 \mathrm{ml}$ kemudian ditambahkan aquades sampai batas akhir $100 \mathrm{ml}$.

\subsubsection{Prinsip Kerja Atomic Absorption Spectrophotometry}

Alat Atomic Absorption Spectrophotometry (AAS) telah diset terlebih dulu sesuai dengan instruksi dalam manual alat. Kemudian dilakukan kalibrasi dengan kurva standart dari masing-masing logam $\mathrm{Cu}$ dan $\mathrm{Pb}$ dengan konsentrasi $0 ; 0,2 ; 0,4 ; 0,6 ; 0,8 ; 1 \mathrm{ppm}$. Kemudian diukur absorbansi dan konsentrasi masing-masing sampel. Alur kerja penelitian dapat dilihat pada Lampiran 1.

\subsubsection{Analisis Data}

\subsubsection{Konsentrasi Logam Berat}

Untuk mendapatkan nilai konsentrasi logam berat yang dianalisis digunakan rumus:

$$
K \text { sebenarnya }\left(\frac{m g}{L}\right)=\frac{K A A S\left(\frac{m g}{L}\right) \times \text { Vol.Pelarut }(L)}{\text { Berat Sampel }(m g)}
$$

Untuk mendapatkan konsentrasi logam berat sebenarnya pada air maka digunakan rumus:

$$
K \text { sebenarnya }\left(\frac{L}{k g}\right)=\frac{K A A S\left(\frac{m g}{L}\right) \times \text { Larutan Sampel }(L)}{\text { Berat Sampel }(m l)}
$$

Keterangan :

K.AAS

K. Sebenarnya

Vol Pelarut

Larutan Sampel

Berat Sampel
: Konsentrasi yang tertera pada alat AAS

: Konsentrasi sebenarnya

: Volume pelarut

: Volume larutan sampel pada saat pengujian

: Berat sampel yang akan diuji

\subsubsection{Faktor Biokonsentrasi Faktor (BCF)}

Setelah kandungan logam berat dalam air diketahui maka data tersebut digunakan untuk menghitung kemampuan A. marina mengakumulasi logam berat $\mathrm{Cu}$ dan $\mathrm{Pb}$ melalui tingkat biokonsentrasi faktor (BCT) dengan rumus :

$$
B C F C u / P b=\frac{\left[\text { Logam Berat } \frac{C u}{P b}\right] \text { Tumbuhan }}{\left[\text { Logam Berat } \frac{C u}{P b}\right] \text { Air }}
$$

$$
\begin{array}{ll}
\mathrm{BCF}>1000 & =\text { Kemampuan mengakumulasikan tinggi } \\
1000>\mathrm{BCF}>250 & =\text { Kemampuan mengakumulasikan sedang } \\
\mathrm{BCF}<250 & =\text { Kemampuan mengakumulasikan rendah }
\end{array}
$$

\subsubsection{Analisis Deskriptif}

Data yang diperoleh dianalisis secara deskriptif sesuai dengan baku mutu air laut untuk biota laut yang terdapat dalam keputusan Menteri Negara Lingkungan Hidup (KepMeneg LH) No. 51 Tahun 2004. Sedangkan baku mutu untuk logam berat dalam lumpur atau sedimen di Indonesia belum ditetapkan. Sehingga sebagai acuan digunakan baku mutu yang di keluarkan International Association Dreding Companies (IADS) / Central Dreding Association (CEDA) tahun 1997 mengenai kandungan logam yang dapat ditoleransi. 


\subsubsection{Data Kualitas Air}

Data kualitas air dilakukan dengan cara pengukuran parameter kualitas air seperti suhu udara, suhu air, $\mathrm{pH}$ air dan salinitas (insitu) pada ke enam titik tersebut secara keseluruhan.

\section{Hasil dan Pembahasan}

\subsection{Kondisi Lingkungan Perairan (Suhu Udara, Suhu Air, pH, Air dan Salinitas)}

Kondisi lingkungan perairan hasil pengukuran secara insitu di lapangan, menunjukkan hasil yang berbeda dari satu titik ke titik lainnya. Suhu udara dan suhu air yang tertinggi terdapat di Hutan Mangrove Belawan demikian juga dengan $\mathrm{pH}$ air dan salinitas pada kawasan Mangrove tersebut. Hasil analisis parameter kualitas perairan dari 6 transek / stasiun yang dilakukan pengambilan sampel pada satu lokasi yang diamati tersaji pada Tabel 1. Diagram rata-rata parameter kualitas lingkungan perairan pada Tumbuhan A. marina tersaji pada Gambar 4.

Tabel 1. Analisis Parameter Kualitas Lingkungan Perairan pada tumbuhan A. marina

\begin{tabular}{lllcccc}
\hline & \multicolumn{2}{l}{ Stasiun / Transek } & & & \\
Parameter & I & II & III & IV & V & VI \\
\hline pH air & 7 & 7 & 7,1 & 7 & 7,1 & 7,1 \\
Salinitas (ppt) & 20,1 & 23,4 & 21 & 24 & 23 & 25 \\
Suhu air $\left({ }^{\circ} \mathrm{C}\right)$ & 30 & 30 & 30 & 31 & 30 & 31 \\
Suhu udara $\left({ }^{\circ} \mathrm{C}\right)$ & 30 & 31 & 30 & 31 & 30 & 31 \\
Diameter & 25 & 25 & 24,5 & 23 & 22 & 24 \\
\hline
\end{tabular}

Keterangan: Transek di Muara Sungai Kawasan Pesisir Belawan

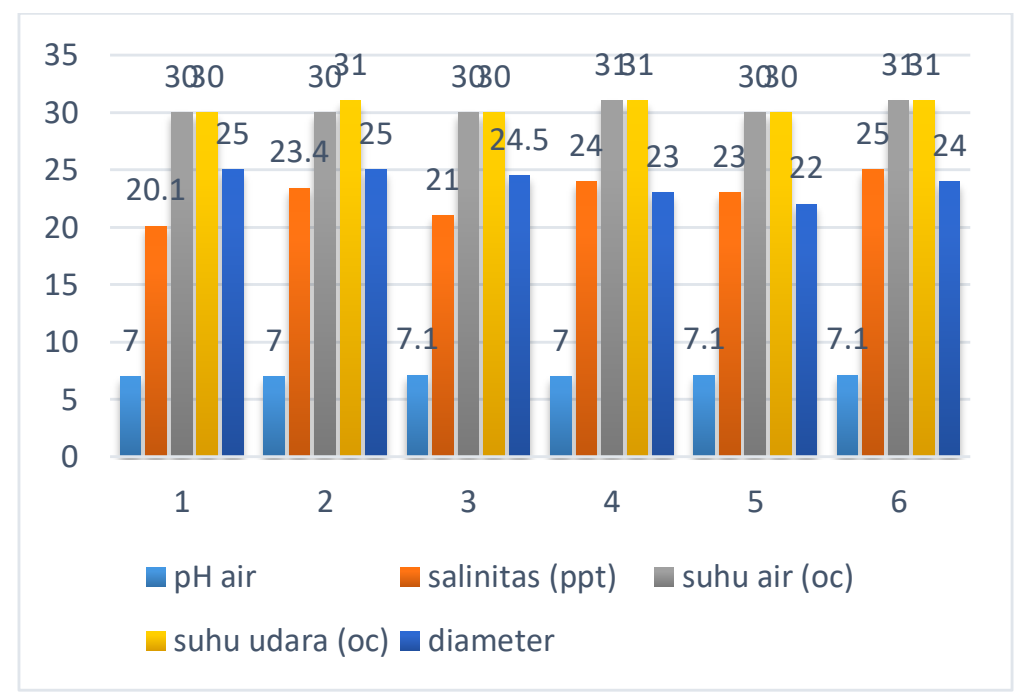

Gambar 4. Diagram Parameter Kualitas Lingkungan Perairan pada tanaman A.marina

Suhu udara pada saat pengambilan sampel dikawasan Hutan Mangrove Desa Nelayan berkisar antara $30-31^{\circ} \mathrm{C}$. Kisaran suhu tersebut dapat di kategorikan sebagai suhu yang tinggi. Hal ini diduga karena tingginya intensitas cahaya matahari pada saat dilakukannya pengukuran. Tingginya intensitas cahaya matahari ini akan mempengaruhi suhu udara dan dapat menyebabkan tingginya tingkat penyerapan panas ke dalam perairan. Sampel diambil tiga waktu yaitu yaitu pagi antara pukul 8.00 WIB hingga pukul $10.00 \mathrm{WIB}$, siang antara pukul $13.00 \mathrm{WIB}$ hingga $15.00 \mathrm{WIB}$, dan sore antara pukul 16.00 WIB hingga 18.00 WIB.

Menurut [5], secara umum kenaikan suhu terjadi karena emisi dari matahari yang sampai di permukaan bumi langsung diterima oleh muka bumi, kurang atau tanpa adanya penyerap sinar yang lain. Fenomena ini biasa terjadi 
pada kondisi lahan yang pada awalnya penggunaan lahan/liputan lahan memiliki potensi sebagai pengendali bahang terasa (sensible heat) alami, menjadi kurang berpotensi atau bahkan tidak berpotensi. Contoh nyata adalah daerah hutan yang berubah menjadi daerah perkotaan. Daerah hutan memiliki banyak vegetasi yang mengurangi pantulan cahaya sebagai bagian dari spektrum radiasi baik sinar langsung maupun sinar yang dipantulkan oleh obyek lain di sekitar vegetasi. Vegetasi juga memiliki kemampuan menyerap $\mathrm{CO}_{2}$ yang terkandung di atmosfer, sehingga dapat mengurangi efek rumah kaca.

Suhu merupakan salah satu parameter yang sangat penting bagi keberlangsungan hidup biota laut. Suhu dapat mempengaruhi proses-proses seperti fotosintesis dan respirasi. Selain itu suhu juga dapat menjadi faktor pembatas bagi biota tertentu. Dari keseluruhan jenis vegetasi mangrove ditemukan pada tiap transek dilokasi Hutan Mangrove Desa Nelayan cocok ataupun ideal pada suhu tersebut sesuai Baku Mutu Kepmen LH No. 51 Tahun 2004 yang menyebutkan bahwa suhu air yang ideal untuk kawasan mangrove ialah $28-33{ }^{\circ} \mathrm{C}$

Suhu air pada saat pengambilan sampel A. marina pada keenam transek di perairan Belawan Desa Nelayan adalah berikisar $30-31^{\circ} \mathrm{C}$, dimana suhu rata-rata ialah $30,33^{\circ} \mathrm{C}$. Perbedaan suhu air pada tiap pengukuran diakibatan oleh intensitas cahaya yang mengenai air, maupun akibat adanya perbadaan penutupan permukaan air pada masing-masing transek. Untuk transek pertama dan kedua didapati A.marina yang berukuran lebih kecil dan proyeksi penutupan tajuk terlihat lebih sempit, sedangkan pada transek ketiga sampai transek keenam berbanding terbalik. Suhu sangat berpengaruh terhadap penyebaran dan komposisi organisme. Kisaran suhu yang baik pada organisme perairan adalah antara18-30 ${ }^{\circ} \mathrm{C}$. Pernyataan tersebut didukung oleh [6] yang menyatakan bahwa nilai kisaran suhu perairan selama penelitian $\left(22-30^{\circ} \mathrm{C}\right)$ tergolong baik.

Adapun nilai $\mathrm{pH}$ rata-rata pada keseluruhan traksek ialah 7,05. Nilai $\mathrm{pH}$ air yang diperoleh dari dua stasiun pengamatan bersifat netral. Nilai $\mathrm{pH}$ pada suatu perairan mempunyai pengaruh yang besar terhadap organisme perairan sehingga seringkali dijadikan petunjuk untuk menyatakan baik buruknya suatu perairan. $\mathrm{pH}$ air tertinggi terdapat pada transek kedua, kelima, dan keenam karena lebih dekat dengan muara sungai sehingga sumber airnya lebih banyak berasal dari air laut. menurut [7], perairan yang lebih dominan dipengaruhi oleh air laut akan bersifat basa, karena derajat keasaman $(\mathrm{pH})$ air laut cenderung bersifat basa.

Salinitas merupakan gambaran dari jumlah dalam yang ada dalam suatu perairan. Sebaran salinitas di air laut juga dipengaruhi oleh berbagai faktor misalnya pola sirkulasi air, penguapan, curah hujan ataupun aliran sungai. Penurunan salinitas ataupun $\mathrm{pH}$ serta naiknya suhu akan menyebabkan tingkat bioakumulasi semakin besar, ketersediaan logam berat yang semakin membesar atau meningkat. Hal ini sesuai dengan pernyataan [8] yang menyatakan bahwa hasil pengukuran salinitas pada keenam stasiun, kisaran salinitas pada stasiun pertama sampai stasiun keenam antara 20 - 25 ppt dengan nilai rata-rata 23,4 ppt. Perbedaan salinitas pada keenam stasiun tersebut disebabkan oleh waktu pengambilan sampel, pasang surut air laut, serta pasokan air yang lebih dominan antara air tawar dengan air laut. Pada transek pertama hutan mangrove sudah banyak yang dikonversi menjadi tambak dan kolam ikan, dalam pengelolaan tambak dan kolam ikan terdapat pompa yang mengambil air laut dan dimasukkan kedalam tambak sehingga mempengaruhi salinitas pada daerah tersebut.

\subsection{Kandungan Logam Berat $C u$ dan Pb pada Akar, Daun dan Kulit Batang A. marina}

Berdasarkan hasil pengukuran kandungan logam berat $\mathrm{Cu}$ dan $\mathrm{Pb}$ pada daun, kulit batang, akar kawat dan akar pasak pada pohon A. marina. (Tabel 2) diperoleh diagram rata-rata kandungan logam berat daun, kulit batang, dan akar yang tersaji pada Gambar 5. Data dasar konsentrasi logam berat secara lengkap disajikan pada Lampiran 2 dan Lampiran 3.

Tabel 2. Analisis Rata-Rata kandungan Logam Berat $\mathrm{Cu}$ dan $\mathrm{Pb}$ dalam daun, kulit batang, akar pasak dan akar kawat A. marina

\begin{tabular}{lll}
\hline Sampel & $\mathrm{Cu}(\mathrm{mg} / \mathrm{kg})$ & $\mathrm{Pb}(\mathrm{mg} / \mathrm{kg})$ \\
\hline Daun & 5,5599 & 0,7730 \\
Kulit batang & 8,1708 & 0,9341 \\
Akar pasak & 4,9633 & 1,1874 \\
Akar Kawat & 12,5705 & 1,5268 \\
\hline
\end{tabular}




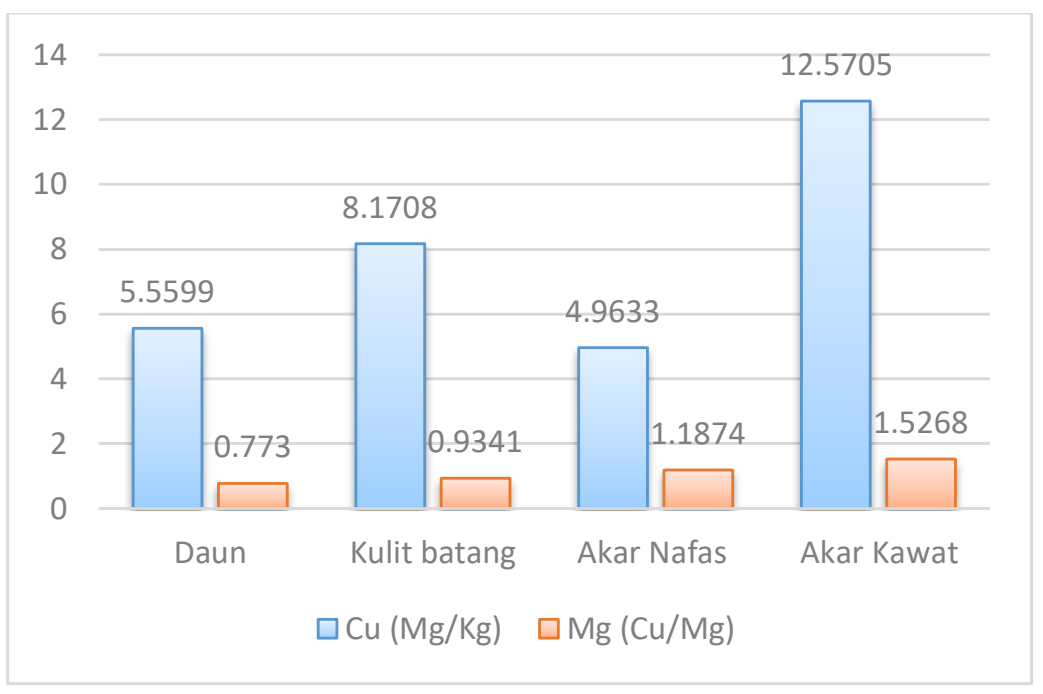

Gambar 5. Diagram Kandungan logam berat $\mathrm{Cu}$ dan $\mathrm{Pb}$ dalam daun, kulit batang, akar pasak dan akar kawat A. marina

Berdasarkan hasil pengukuran, logam berat $\mathrm{Cu}$ dan $\mathrm{Pb}$ pada daun pohon Avicennia marina cukup tinggi. Rata-rata kandungan $\mathrm{Cu}$ pada daun pohon $A$. marina sekitar 5,5599 mg/kg dan rata-rata kandungan $\mathrm{Pb}$ sekitar 0,7730 mg/kg. Kandungan $\mathrm{Cu}$ pada bagian daun cukup tinggi sebelum di rata-ratakan dan setiap stasiun berbeda kandungannya. Hal ini disebabkan diameter batang pohon yang berbeda pada keenam stasiun dan perbandingan antara daun tua (pada pangkal dengan ukuran yang cukup besar, ketebalan dan warna daun hijau tua) dan daun muda (pada pucuk, ukuran kecil, belum terlalu tebal dan warna daun hijau muda) yang dikompositkan. Menurut [9], kandungan logam berat pada daun muda lebih sedikit dibandingkan dengan daun tua.

Menurut [10], proses absorpsi racun, termasuk logam berat terjadi melalui bagian tumbuhan, seperti daun bagi zat yang lipofilik. Hasil pengukuran konsentrasi logam $\mathrm{Cu}$ tertinggi pada daun A. marina terdapat pada stasiun keenam dan hasil pengukuran terendah terdapat pada stasiun kelima dan hasil pengukuran konsentrasi logam $\mathrm{Pb}$ tertinggi pada daun A. marina terdapat pada Stasiun ketiga dan yang terendah terdapat pada Stasiun pertama. Menurut [11], mangrove merupakan tumbuhan tingkat tinggi di kawasan pantai yang dapat berfungsi untuk menyerap bahanbahan organik dan non-organik sehingga dapat dijadikan bioindikator logam berat. Hal ini di dukung oleh penelitian yang dilakukan [12] yang menjelaskan bahwa tumbuhan A. marina mampu mengakumulasi logam berat. Begitu pula penelitian yang dilakukan oleh [13] juga menjelaskan bahwa tumbuhan A. marina juga mampu mengakumulasi logam berat $\mathrm{Cu}$ di bagian daun, baik daun muda maupun daun tua. $\mathrm{Cu}$ juga sangat berguna untuk pertumbuhan jaringan tumbuhan terutama jaringan daun dimana terdapat proses fotosintesis [14].

\subsection{Kandungan Logam Berat $\mathrm{Cu}$ dan Pb pada Air dan Sedimen}

Berdasarkan hasil pengukuran kandungan logam berat $\mathrm{Cu}$ dan $\mathrm{Pb}$ pada kawasan Hutan Mangrove di Desa Nelayan didapati 5,061 dan 0,8115 untuk kualitas air sedangkan pada sedimen didapati 17,4574 dan 3,1295. Tabel 3 menunjukkan analisis rata-rata kandungan logam berat $\mathrm{Cu}$ dan $\mathrm{Pb}$ pada Kualitas air dan sedimen dari keenam transek. Diagram rata-rata Kandungan Logam Berat $\mathrm{Cu}$ dan $\mathrm{Pb}$ pada Air dan Sedimen dapat dilihat pada Gambar 6.

Tabel 3. Analisis Rata-Rata Kandungan Logam Berat $\mathrm{Cu}$ dan $\mathrm{Pb}$ pada Air dan Sedimen

\begin{tabular}{llll}
\hline SAMPEL & $\mathrm{Cu}(\mathrm{mg} / \mathrm{kg})$ & $\mathrm{Pb}(\mathrm{mg} / \mathrm{kg})$ & BAKU MUTU \\
\hline \multirow{2}{*}{ Air } & 5,061 & 0,8115 & KEPMEN KLH No. 51 Tahun \\
& & $2004(0,008 \mathrm{mg} / \mathrm{l})$. \\
\multirow{2}{*}{ Sedimen } & 17,4574 & 3,1295 & IADC/CEDA 1997 \\
& & & $\mathrm{Cu}(600 \mathrm{mg} / \mathrm{kg})$ \\
& & $\mathrm{Pb}(1000 \mathrm{mg} / \mathrm{kg})$. \\
\hline
\end{tabular}




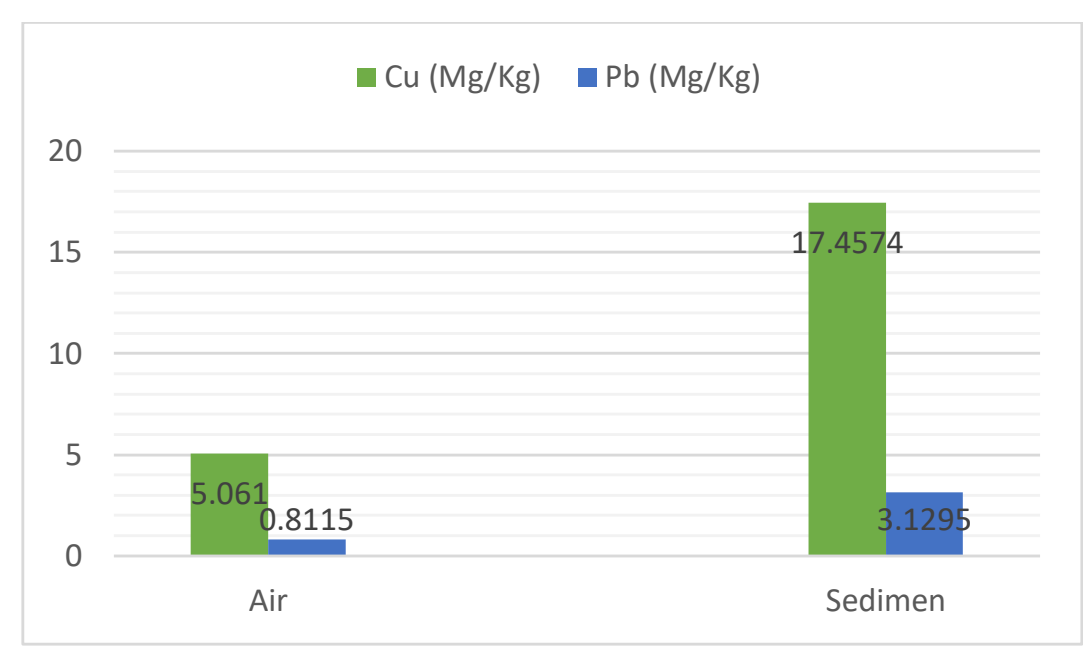

Gambar 6. Diagram Kandungan Logam Berat $\mathrm{Cu}$ dan $\mathrm{Pb}$ pada Air dan Sedimen

Dari hasil pengukuran kualitas air logam berat Cu sebesar 5,061 L/kg. Kandungan logam berat Cu di kategorikan tinggi. Pada saat pengambilan sampel dilakukan pada saat pasang mati (sedikit air pasang yang masuk ke dalam lokasi tersebut). Dari pengukuran kualitas air rata - rata kandungan logam berat Pb sebesar 0,8115 L/kg. Menurut [15], pencemaran suatu perairan laut oleh unsur-unsur logam berat selain mengganggu ekosistem hal tersebut juga secara tidak langsung dapat merusak organisme laut dan berimbas pada kesehatan manusia.

Dari hasil pengukuran kandungan logam berat $\mathrm{Cu}$ dan $\mathrm{Pb}$ pada sedimen di lokasi Belawan, pengambilan sampel rata-rata kandungan logam berat $\mathrm{Cu}$ adalah sebesar $17,45574 \mathrm{mg} / \mathrm{kg}$. Kandungan logam berat $\mathrm{Cu}$ tinggi dikarenakan banyaknya kegiatan industri. Menurut [16] dalam penentuan kadar logam yang masih dapat ditoleransi pada sedimen yaitu untuk $\mathrm{Cu}$ sebesar $600 \mathrm{mg} / \mathrm{kg}$, maka pencemaran $\mathrm{Cu}$ pada lokasi Kawasan Pesisir Belawan masih dapat ditoleransi. Nilai rata-rata kandungan logam berat $\mathrm{Pb}$ sebesar 3,1295 mg/kg. Menurut [16] dalam penentuan kadar logam yang masih dapat ditoleransi pada sedimen yaitu untuk $\mathrm{Pb}$ sebesar $1000 \mathrm{mg} / \mathrm{kg}$. Kandungan logam berat $\mathrm{Pb}$ pada sedimen di lokasi Pengamatan Kawasan Pesisir Belawan masih masuk ke dalam batas toleransi.

Kandungan $\mathrm{Cu}$ dan $\mathrm{Pb}$ air lebih rendah dibandingkan kandungan $\mathrm{Cu}$ dan $\mathrm{Pb}$ pada sedimen. Hal ini terjadi sesuai dengan sifat logam tersebut dan hal ini berkaitan dengan tingginya kandungan logam berat $\mathrm{Cu}$ dan $\mathrm{Pb}$ pada air akan mengalami pengendapan atau sedimentasi pada dasar perairan. Selain itu menurut [17], jenis susbtrat dan ukurannya merupakan salah satu faktor ekologi yang mempengaruhi kandungan bahan organik. Semakin halus tekstur substrat maka akan semakin besar kemampuannya mengikat bahan organik. Logam berat memiliki sifat yang mudah mengikat bahan organik dan akan mengendap di dasar perairan dan akan berikatan dengan partikel-partikel sedimen, hal tersebut menyebabkan konsentrasi logam berat pada sedimen akan lebih tinggi dibandingkan logam berat pada air [8].

\subsection{Faktor Biokonsentrasi (BCF) untuk Menilai Kemampuan A. marina dalam Mengakumulasi Logam Berat Cu dan $\mathrm{Pb}$}

Berdasarkan hasil perhitungan nilai faktor biokonsentrasi (BCF) diketahui bahwa nilai BCF tertinggi adalah untuk $\operatorname{logam} \mathrm{Cu}$ yaitu 6,17755 dan nilai BCF terendah 5,4484 untuk logam $\mathrm{Pb}$. Nilai faktor biokonsentrasi $\mathrm{Cu}$ dan $\mathrm{Pb}$ di enam transek pengamatan disajikan pada Tabel 4.

Tabel 4. Nilai Faktor Biokonsentrasi (BCF) $\mathrm{Cu}$ dan $\mathrm{Pb}$ di Kawasan Pesisir Belawan

\begin{tabular}{|c|c|c|c|c|c|}
\hline Konsentrasi $\mathrm{Cu}$ & & & Konsentrasi P & & \\
\hline $\begin{array}{l}\text { Tumbuhan = } \\
\text { total akar } \\
\text { kawat, akat } \\
\text { nafas, kulit }\end{array}$ & $\begin{array}{l}\text { Air } \\
(\mathrm{L} / \mathrm{kg})\end{array}$ & $\begin{array}{l}\mathrm{BCF} \mathrm{Cu} \\
(\mathrm{L} / \mathrm{kg})\end{array}$ & $\begin{array}{l}\text { Tumbuhan = } \\
\text { total akar } \\
\text { kawat, akat } \\
\text { pasak, kulit }\end{array}$ & $\begin{array}{l}\text { Air } \\
(\mathrm{L} / \mathrm{kg})\end{array}$ & $\mathrm{BCF} \mathrm{Pb}(\mathrm{L} / \mathrm{kg})$ \\
\hline
\end{tabular}




\begin{tabular}{|c|c|c|c|c|c|}
\hline $\begin{array}{l}\text { batang dan } \\
\text { daun }(\mathrm{mg} / \mathrm{kg})\end{array}$ & & & $\begin{array}{l}\text { batang dan } \\
\text { daun }(\mathrm{mg} / \mathrm{kg})\end{array}$ & & \\
\hline 31,2646 & 5,061 & 6,17755 & 4,4214 & 0,8115 & 5,4484 \\
\hline
\end{tabular}

Faktor biokonsentrasi (BCF) adalah konsentrasi suatu senyawa di dalam suatu organisme percobaan dibagi dengan konsentrasi senyawa tersebut dalam medium air satuannya (L/kg). Untuk mendapatkan faktor biokonsentrasi dari $A$. marina maka kandungan logam berat $\mathrm{Cu}$ dan $\mathrm{Pb}$ dari akar kawat, akar pasak, kulit batang dan daun dibagi dengan konsentrasi logam berat $\mathrm{Cu}$ dan $\mathrm{Pb}$ pada air dari transek. Faktor biokonsentrasi di hitung untuk melihat kemampuan A. marina dalam mengakumulasi logam berat $\mathrm{Cu}$ dan $\mathrm{Pb}$.

Berdasarkan hasil perhitungan biokonsentrasi, dapat diketahui bahwa A. marina memiliki kemampuan mengakumulasi logam berat $\mathrm{Cu}$ dan $\mathrm{Pb}$. Nilai akumulasi logam berat $\mathrm{Cu}$ lebih besar dibandingkan logam berat $\mathrm{Pb}$. Dengan nilai BCF Cu sebesar 6,17755 dan nilai tersebut dapat dikatakan rendah dan nilai BCF Pb sebesar 5,4484 juga dikategorikan rendah. Logam berat $\mathrm{Cu}$ kemungkinan lebih besar untuk diserap tumbuhan, karena merupakan logam esensial bagi tumbuhan. Perbedaan tersebut diduga disebabkan oleh proses masuknya logam $\mathrm{Pb}$ pada jaringan. Menurut [11], $\mathrm{Pb}$ merupakan logam yang sangat rendah daya larutnya bersifat pasif dan mempunyai daya translokasi yang rendah mulai dari akar sampai organ tumbuhan lainnya.

Avicennia marina merupakan spesies mangrove yang sangat ketat dalam menyerap logam $\mathrm{Pb}$ bahkan sampai tidak menyerap sama sekali. Dalam hal ini nampaknya barier pada akar mangrove merupakan penghalang bagi unsur-unsur logam berat untuk sampai ke berbagai jaringan tanaman yang sensitif. Ketika konsentrasi logam berat pada sedimen tinggi, mangrove secara aktif akan menggurangi penyerapan logam berat. Terkadang akar juga mempunyai sistem penghentian transpor logam menuju daun terutama logam non esensial, sehingga ada penumpukkan logam di akar [18] yang artinya penyerapan tetap dilakukan, namun dalam jumlah yang terbatas dan terakumulasi di akar. Selain itu, terdapat sel endodermis pada akar yang menjadi penyaring dalam proses penyerapan logam berat.

Data faktor biokonsentrasi tersebut membuktikan bahwa pohon A. marina memiliki kecenderungan untuk menyerap dan mengakumulasikan logam berat di dalam ekosistem habitatnya. Perbedaan konsentrasi logam berat organ tumbuhan tertentu berkaitan dengan proses fisiologis tubuhan tersebut. Menurut [19] terdapat tiga jalan yang dapat ditempuh oleh air dan ion-ion yang terlarut bergerak dan menuju sel-sel xylem dalam akar, antara lain; (1) melalui dinding sel (apoplas) epidermis dan sel-sel korteks, (2) melalui sistem sitoplasma (simplas) yang bergerak dari sel ke sel, dan (3) melalui sel hidup pada akar dimana sitosol dari tiap-tiap sel membentuk suatu jalur.

Menurut [20], secara umum tumbuhan melakukan penyerapan oleh akar, baik yang berasal dari sedimen maupun air, kemudian terjadi translokasi ke bagian tumbuhan yang lain dan lokalisasi atau penimbunan logam pada jaringan tertentu. Pada tumbuhan secara umum logam $\mathrm{Cu}$ merupakan logam esensial yang dibutuhkan tumbuhan untuk pertumbuhannya, yaitu sebagai activator enzim. Selain memiliki kemampuan mengakumulasi logam berat dilingkungan pada bagian-bagian tubuhnya, A. marina juga dapat melakukan alokasi dan menurunkan kadar toksisitas logam berat, diantaranya dengan melemahkan efek racun melalui pengenceran (dilusi), dengan menyimpan banyak air untuk mengencerkan konsentrasi logam berat dalam jaringan tumbuhan A. marina. Pengenceran dengan cara penyimpanan air pada jaringan biasa terjadi pada daun dan diikuti dengan terjadinya penebalan daun. Eksresi juga merupakan upaya yang mungkin akan terjadi dengan menyimpan materi toksik logam berat didalam jaringan tubuh yang sudah tua. Logam berat yang masuk kedalam jaringan akan mengalami pengikatan dan penurunan daya racun karena diolah menjadi persenyawaan yang lebih sederhana.

\subsection{Kandungan Logam Berat $\mathrm{Cu}$ dan Pb Pada Kulit Batang A. marina}

Hasil pengukuran logam berat $\mathrm{Cu}$ dan $\mathrm{Pb}$ pada akar pohon A. marina menunjukkan hasil yang lebih rendah dibandingkan kandungan pada kulit batang dan daun. Rata-rata kandungan $\mathrm{Cu}$ pada kulit batang $\mathrm{A}$. marina sekitar $8,1708 \mathrm{mg} / \mathrm{kg}$. Rata-rata kandungan $\mathrm{Pb}$ sekitar $0,9341 \mathrm{mg} / \mathrm{kg}$. Hasil pengukuran konsentrasi logam $\mathrm{Cu}$ tertinggi pada kulit batang A. marina terdapat pada stasiun kedua dan terendah pada stasiun pertama dan hasil pengukuran 
konsentrasi logam $\mathrm{Pb}$ tertinggi pada kulit batang A. marina terdapat pada stasiun keempat dan terendah pada stasiun kedua dengan nilai rata-rata logam berat $\mathrm{Cu}$ sebesar 5,5599 dan rata-rata logam berat $\mathrm{Pb}$ sebesar 0,7730..

Perbedaan kandungan logam berat $\mathrm{Cu}$ dan $\mathrm{Pb}$ pada setiap stasiun pengamatan disebabkan oleh diameter batang pohon mangrove yang bervariasi. Perbedaan diameter batang pohon menentukan banyaknya logam berat dan zat-zat lain yang terakumulasi di dalam pohon tersebut. Menurut [21] semakin besar diameter batang pohon, maka usia pohon juga semakin tua sehingga akumulasi zat-zat yang terdapat di dalam pohon tersebut semakin besar. Senyawa logam berat yang terdapat didalam pembuluh pengangkut dan kulit batang tanaman dapat terlokalisasi dengan baik.

\subsection{Kandungan Logam Berat Cu dan Pb Pada Akar A. marina}

Hasil pengukuran logam berat $\mathrm{Cu}$ dan $\mathrm{Pb}$ pada akar pohon A. marina menunjukkan hasil yang lebih rendah dibandingkan kandungan pada kulit batang dan daun. Rata-rata kandungan logam berat $\mathrm{Cu}$ pada akar pasak pohon A. marina sekitar 4,9633 mg/kg. Rata-rata kandungan logam berat $\mathrm{Pb}$ sekitar $1,1874 \mathrm{mg} / \mathrm{kg}$ sedangkan untuk akar kawat mempunyai nilai rata-rata kandungan logam berat $\mathrm{Cu}$ sekitar $12,5705 \mathrm{mg} / \mathrm{kg}$. rata-rata kandungan logam berat $\mathrm{Pb}$ sekitar $1,5268 \mathrm{mg} / \mathrm{kg}$.

Berdasarkan hasil analisis, di ketahui bahwa data akar kawat lebih besar mengandung logam berat $\mathrm{Cu}$ ataupun $\mathrm{Pb}$ dibandingkan akar pasak. Hal ini dapat dikatakan wajar, karena disebabkan oleh distribusi unsur hara dan garamgaram mineral yang tidak sama di setiap bagian tumbuhan dan hal tersebut dipengaruhi oleh beberapa faktor. Besarnya kandungan logam berat pada akar kawat di duga karena lebih banyaknya variasi dan interaksi dengan sedimen yang sudah mengandung banyak logam berat yang sebelumnya mengendap dibandingkan dengan akar pasak yang hanya berinteraksi dengan kandungan logam berat pada kolom air, seperti hal yang dikemukakan oleh [22] yang menyatakan bahwa unsur hara dapat kontak dengan permukaan akar melalui tiga cara yaitu dengan cara: Difusi dalam larutan tanah, secara pasif terbawa oleh aliran air tanah dan karena akar kontak dengan hara tersebut didalam matrik tanah. Namun secara keseluruhan analisis, adapun akar nafas ataupun akar kawat dapat menyerap logam berat dengan jumlah konsentrasi berlipat ganda jika hal tersebut dibandingkan dengan logam berat pada air.

\section{Kesimpulan dan Saran}

\subsection{Kesimpulan}

Dari penelitian yang dilakukan diketahui kandungan logam berat $\mathrm{Cu}$ pada daun Avicennia marina di Kawasan Pesisir Belawan sebesar 5,5599 mg/kg > Pb 0,7730 mg/kg. Kandungan Cu pada kulit batang A.marina 8,1708 mg/kg $>\mathrm{Pb} 0,9341 \mathrm{mg} / \mathrm{kg}$. Kandungan Cu pada akar pasak A. marina $4,9633 \mathrm{mg} / \mathrm{kg}>\mathrm{Pb} 1,1874 \mathrm{mg} / \mathrm{kg}$. Kandungan Cu pada akar kawat $A$. marina $12,5705 \mathrm{mg} / \mathrm{kg}>\mathrm{Pb} 1,5268 \mathrm{mg} / \mathrm{kg}$. Sedimen memiliki kandungan $\mathrm{Cu} 17,4574 \mathrm{mg} / \mathrm{kg}<0,8115$ $\mathrm{mg} / \mathrm{kg}$. Kandungan logam berat $\mathrm{Cu}$ pada air $5,061 \mathrm{mg} / \mathrm{L}>\mathrm{Pb} 0,081 \mathrm{mg} / \mathrm{L}$. Kemampuan A. marina dalam mengakumulasi logam berat $\mathrm{Cu}$ dan $\mathrm{Pb}$ dapat dikategorikan rendah karena nilai $\mathrm{BCF}$ pada akumulasi logam berat $\mathrm{Cu}$ dan $\mathrm{Pb}<250$.

\subsection{Saran}

Avicennia marina memiliki kemampuan untuk mengurangi konsentrasi logam berat $\mathrm{Cu}$ dan $\mathrm{Pb}$ dalam air dan juga sedimen. Data yang diperoleh merupakan hasil dari satu kali pengambilan sampel yang artinya merupakan gambaran data kadar logam berat pada saat dilakukan sampling saja. Oleh karena itu perlu dilakukan peneitian lanjutan untuk mengembangkan dan menghasilkan data secara periodik.

\section{Referensi}

[1] Noor Y.R., Kazali M, Suryadiputra, I.N.N. (1999) "Panduan Pengenalan Mangrove di Indonesia”, Wetland International Indonesia Programme

[2] Pramudji (2001) "Ekosistem Hutan Mangrove dan Peranannya Sebagai Habitat Berbagai Fauna Aquatik.” Oseana 26 (4):13-23 ISSN 0216$1877: 13-14$. 
[3] Martinuzzi S., W. A. Gould, A Lugo, dan E. Medina (2009) “Conversion and Recovery of Puerto Rican Mangroves: 200 Years of Change.” Journal Forest Ecology and Management 257: 75-84.

[4] Kartikasari V., Tandjung S., Sunarto (2002) “Akumulasi Logam Berat Ct Dan Pb pada Tumbuhan Mangrove Avicennia marina di Muara Sungai Babon Perbatasan Kota Semarang dan Kabupaten Demak Jawa Tengah.” Manusia dan Lingkungan 60 (3): I37-117.

[5] Noor A. (2013) "Halaman Judul Studi Pulau Bahang (Head island) di Komplek Universitas Gadjah Mada", Universitas Gadjah Mada

[6] Muarif (2016) "Karakteristik Perairan di Kolam Budidaya Perikanan.” Jurnal Mina Sains 2 (2) ISSN: 2407-9030

[7] Effendi H. (2003) “Telaah Kualitas Air Bagi Pengelolaan Sumberdaya dan Lingkunan Perairan”, Yogyakarta, Kanisius

[8] Hutagalung H.P. (1991) "Pencemaran Laut oleh Logam Berat dalam Beberapa Perairan Indonesia”, Jakarta, Puslitbang, Oseanologi LIPI Hlm $45-59$

[9] Singh K.P. (2013) "Akumulasi Logam Berat Tembaga (Cu) dan Timbal (Pb) pada Pohon Rhizophora mucronata di Hutan Mangrove Desa Nelayan Kecamatan Medan Labuhan dan Desa Jaring Halus Kecamatan Secanggang”, dalam skripsi Jurusan Budidaya Hutan, Universitas Sumatera Utara, Medan

[10] Soemirat J. (2003) “Toksikologi Lingkungan”, Yogyakarta, Gajah Mada University Press

[11] Mac Farlane G.R., Pulkownik, Burchett (2003) "Accumulation and Distribution of Heavy Metals in Grey Mangrove, Avicennia marina (Forsk) Vierh: Biological Indication Potential.” Environmental Pollution 123: 139-151.

[12] Rohmawati (2007) "Daya Akumulasi Tumbuhan Avicennia marina Terhadap Logam Berat (Cu, Cd, Hg) Di Pantai Kenjeran Surabaya”, dalam Skripsi Jurusan Biologi Fakultas Sains dan Biologi, Universitas Islam Negeri Malang

[13] Amin B. (2001) "Akumulasi dan Distribusi Logam Berat Pb dan Cu pada Mangrove (Avicennia marina) di Perairan Pantai Dumai, Riau." Jurnal Natur Indonesia 4 (1): 80-86.

[14] Kamaruzzaman B.Y. M.C. Ong KCA, Jalal S, Shahbudin, Nor. (2008) “Accumulation of Lead and Copper in Rhizophora apiculata from Setiu Mangrove Forest, Terengganu, Malaysia." Journal of Environmental Biology 821-824.

[15] Darmono (1995) “Logam Dalam Sistem Biologi Mahluk Hidup”, Jakarta, UI-Press

[16] IACD/CEDA (1997) "Conventions, Codes, and Conditions Marine Disporsal.Environmental Aspects of Dredging"

[17] Nybakken J.W. (1992) “Biologi Laut. Suatu Pendekatan Ekologis.” Jakarta, Gramedia

[18] Yoon J.C., Xinde Z., Qixing, L.Q. Ma. (2006) “Accumulation of Pb, Cu, and Zn in Native Plants Growing on a Contaminated Florida Site." Science of the Total Environment 456-464.

[19] Rosmarkam A dan Nasih W.Y. (2002) "Ilmu Kesuburan Tanah”, Yogyakarta, Penerbit Kanisius

[20] Palar H. (2004) "Pencemaran dan Toksikologi Logam Berat", Cet: 2. Jakarta, PT. Rineka Cipta

[21] Andani S., Purbayanti (1981) “Fisiologi Lingkungan Tanaman”, Yogyakarta, Gadjah Mada University Press

[22] Lakitan B. (2001) “Dasar- Dasar Fsiologi Tumbuhan”, Jakarta, Raja Grafindo Persada 